\title{
Pneumonia Covid-19 dengan Gangguan Ginjal Akut
}

\author{
Rivaldy Wahab, ${ }^{1}$ Efata Polii, ${ }^{2}$ Cerelia Sugeng ${ }^{2}$
}

\author{
${ }^{1}$ Program Studi Pendidikan Dokter Fakultas Kedokteran Universitas Sam Ratulangi, Manado, \\ Sulawesi Utara, Indonesia \\ ${ }^{2}$ Bagian Ilmu Penyakit Dalam Fakultas Kedokteran Universitas Sam Ratulangi, Manado, \\ Sulawesi Utara, Indonesia \\ Email: rivaldywhb@gmail.com
}

\begin{abstract}
SARS-CoV-2 infection causes various symptoms, including mild, moderate, severe, and critical symptoms. Severe SARS-CoV-2 infection can cause pneumonia, acute respiratory syndrome, kidney failure, and even death. This study was aimed to evaluate patients with COVID-19 pneumonia associated with acute kidney injury (AKI). This was a literature review study using three databases, namely PubMed, ClinicalKey, and Google Scholar. The keywords used were acute kidney injury AND pneumonia AND COVID-19. The results showed 10 selected literatures based on inclusion and exclusion criteria. All literatures stated that males dominated the study samples (52.4-73\%). The risk factors of AKI in COVID-19 pneumonia were co-morbidities which were predominantly hypertension, diabetes mellitus, COPD, cardiovascular diseases, and respiratory diseases, as well as nephrotoxic drugs. AKI was the complication of pneumonia COVID-19. The mortality rate was higher among pneumonia COVID-19 patients with AKI compared to pneumonia COVID-19 patients without AKI. In conclusion, AKI is the complication of COVID-19 pneumonia. Nephrotoxic drugs and co-morbidities are the risk factors of AKI in COVID-19 pneumonia. The mortality rate is higher in patients with AKI compared to those without AKI.
\end{abstract}

Keywords: acute kidney injury, pneumonia COVID-19, coronavirus disease 2019

\begin{abstract}
Abstrak: Infeksi SARS-CoV-2 menimbulkan berbagai gejala baik yang ringan, sedang, berat hingga kritis. Infeksi SARS-CoV-2 yang berat dapat menyebabkan pneumonia, sindrom pernapasan akut, gagal ginjal, bahkan kematian. Penelitian ini bertujuan untuk mengetahui gambaran pneumonia COVID-19 dengan gangguan ginjal akut (GGA). Jenis penelitian ialah literature review dengan pencarian data menggunakan tiga database yaitu PubMed, ClinicalKey, dan Google Scholar. Kata kunci yang digunakan ialah acute kidney injury AND pneumonia AND COVID-19. Hasil penelitian mendapatkan 10 literatur berdasarkan kriteria inklusi dan eksklusi. Pada semua literatur didapatkan jenis kelamin laki-laki yang mendominasi sampel penelitian $(52,4-73 \%)$. Riwayat penyakit didominasi oleh hipertensi, diabetes melitus, PPOK, penyakit kardiovaskuler, dan penyakit pernapasan. GGA merupakan komplikasi pada pneumonia COVID-19. Pasien pneumonia COVID19 dengan gangguan ginjal akut memiliki angka kematian yang lebih tinggi dibandingkan dengan pasien pneumonia COVID-19 tanpa gangguan ginjal akut di rumah sakit. Faktor risiko gangguan ginjal akut pada pneumonia COVID-19, antara lain: penggunaan obat yang bersifat nefrotoksik, memiliki komorbid (usia tua, diabetes mellitus, penyakit kardiovaskular, penyakit ginjal kronis, dll). Sinpulan penelitian ini ialah GGA merupakan komplikasi pada pneumonia COVID-19. Penggunaan obat yang bersifat nefrotoksik dan adanya komorbid merupakan faktor risiko terjadinya GGA pada pasien pneumonia COVID-19. Angka kematian lebih tinggi terdapat pada pasien pneumonia COVID-19 dengan GGA dibandingkan dengan yang tanpa GGA.
\end{abstract}

kata kunci: gangguan ginjal akut, pneumonia COVID-19, coronavirus disease 2019 


\section{PENDAHULUAN}

Corona virus disease 2019 (COVID19) disebabkan oleh severe acute respiretory syndrome corona virus 2 (SARS-CoV2). Infeksi SARS-CoV-2 menimbulkan berbagai gejala baik gejala ringan, sedang, berat hingga kritis. ${ }^{1}$ Infeksi SARS-CoV-2 yang berat dapat menyebabkan pneumonia, sindrom pernapasan akut, gagal ginjal, bahkan kematian. ${ }^{2}$ Covid-19 pertama kali diidentifikasi di Kota Wuhan, China pada Desember 2019 sebagai pneumonia yang tidak diketahui penyebabnya, ${ }^{1}$ dan secara global telah mencapai 71.581 .532 kasus dengan 1.618.374 kasus kematian (total kasus per tanggal 15 Desember 2020). ${ }^{3}$

Menurut National Health Commission of China, pada diagnosis and treatment protocols for novel coronavirus pneumonia (Trial Versi 7), pneumonia yang disebabkan oleh COVID-19 diklasifikasikan menjadi pneumonia ringan, sedang, berat dan kritis. Secara klinis pneumonia COVID-19 didefinisikan sebagai demam, batuk, dan sindrom pernapasan. $^{4}$

Kidney Disease: Improving Global Outcomes (KDIGO) (2012) mendefinisikan gangguan ginjal akut (GGA) sebagai peningkatan kreatinin serum $0,3 \mathrm{mg} / \mathrm{dL}$ atau 1,5 kali lebih besar, yang diperkirakan terjadi dalam 7 hari, ataupun penurunan volume urin di bawah $0,5 \mathrm{ml} / \mathrm{kg} / \mathrm{jam}$ selama 6 jam. Tingkat keparahan gangguan ginjal akut menurut pedoman KDIGO (2012) dibagi menjadi 3 tahapan berdasarkan peningkatan serum kreatinin dan penurunan output urin. ${ }^{5}$

Gangguan ginjal akut biasanya terjadi pada pasien sakit kritis dengan COVID-19, yaitu sekitar $20-40 \%$ pasien yang dirawat di perawatan intensif, dan berdasarkan penga- laman dari negara-negara Eropa dan Amerika Serikat, dianggap sebagai penanda tingkat keparahan penyakit dan faktor prognostik untuk bertahan hidup. Penerapan pedoman KDIGO pada pasien sakit kritis dengan keterlibatan ginjal cenderung mengurangi kejadian dan tingkat keparahan GGA di COVID-19, tetapi membutuhkan validasi. Sekitar $20 \%$ pasien yang dirawat di unit perawatan intensif dengan COVID-19 memerlukan terapi penggantian ginjal dengan rerata 15 hari sejak onset terjadinya penyakit. Pengenalan dini keterlibatan ginjal dalam COVID-19 dan penggunaan tindakan pencegahan dan terapeutik untuk membatasi perkembangan gangguan ginjal akut ke tahap yang lebih parah, sangat penting untuk mengurangi morbiditas dan mortalitas. ${ }^{6}$

\section{METODE PENELITIAN}

Penelitian ini dilakukan dalam bentuk literature review berdasarkan hasil penelusuran tiga database yaitu PubMed, Clinical Key, dan Google Scholar dengan kata kunci acute kidney Injury AND pneumonia AND COVID-19. Literatur yang diperoleh kemudian diseleksi dengan kriteria inklusi dan eksklusi sehingga didapatkan literature yang memenuhi kriteria penelitian.

\section{HASIL PENELITIAN}

Setelah dilakukan seleksi literatur, didapatkan 10 artikel full text yang memenuhi kriteria inklusi dan eksklusi. Jumlah sampel penelitian bervariasi, yang berjumlah sampai ribuan penderita covid-19 dengan gangguan ginjal akut. Tabel 1 memperlihatkan hasil kajian artikel yang dipakai dalam penelitian ini,

Tabel 1. Analisis jurnal berdasarkan peneliti, tahun, populasi, ringkasan hasil, dan metode

\begin{tabular}{|c|c|c|c|}
\hline $\begin{array}{c}\text { Peneliti, tahun dan } \\
\text { judul }\end{array}$ & Populasi & Ringkasan hasil & Metode \\
\hline $\begin{array}{l}\text { Kui Jin et al, 2020.7 } \\
\text { Acute kidney injury in } \\
\text { COVID-19: clinical } \\
\text { outcomes and risk } \\
\text { factors }\end{array}$ & 342 pasien & $\begin{array}{l}\text { GGA terjadi pada } 13,4 \%(\mathrm{n}=46) \text {, diantaranya } 7,0 \%(\mathrm{n} \\
=24) \text { berkembang stadium } 1 \text { GGA, dan } 6,4 \%(\mathrm{n}=22) \\
\text { berkembang stadium } 2-3 \text { GGA. Secara keseluruhan } \\
26,9 \%(\mathrm{n}=92) \text { meninggal selama dirawat di rumah sakit. } \\
\text { Diantaranya } 19,3 \% \quad(57 / 296) \text { pasien non-GGA } \\
\text { meninggal, } 62,5 \%(15 / 24) \text { pasien GGA stadium } 1 \text {, dan } \\
90,9 \%(20 / 22) \text { pasien GGA stadium } 2-3 \text { meninggal. }\end{array}$ & $\begin{array}{l}\text { Retrospective } \\
\text { cohort study }\end{array}$ \\
\hline
\end{tabular}


Ki Ryang $\mathrm{Na}$ et al, $2020 .^{8}$

Acute kidney injury and kidney damage in COVID-19 patients

Guanhua Xiao et al, $2020^{9}$

Acute kidney injury in patients hospitalized with COVID-19 in Wuhan, China: a single-center retrospective observational study

Xiaoyang Cui et al, $2020 .^{10}$

Acute kidney injury in patients with the coronavirus disease 2019: a multicenter study

Jamie S. Hirsch et al, $2020 .^{11}$

Acute kidney injury in patients hospitalized with COVID-19

Abdulqareeb Taher et al, $2020,{ }^{12}$

Acute kidney injury in COVID-19 pneumonia: a single-center experience in Bahrain

Ali Monfared et al, $2020 .{ }^{13}$

Clinical characteristics and outcome of COVID-19 pneumonia in kidney transplant recipients in Razi

GGA sangat terkait dengan kematian (HR 2.52; 95\% CI 1.59-3.96; $\mathrm{p}=0.001$ ).

66 pasien

GGA terjadi pada 3 pasien (4,5\%) dari 66 pasien, dan 1 pasien GGA stadium 3 menjalani hemodialisis. Setelah tindak lanjut, semua 3 pasien pulih fungsi ginjal normal. Dibandingkan dengan pasien dengan COVID-19 ringan, GGA ( $\mathrm{n}=3$ ) terjadi pada pasien dengan COVID-19 berat, di antaranya PCR (protein to creatinine ratio) urin dan ACR (albumin to creatinine ratio) yang meningkat.

287 pasien Sebanyak 287 pasien, 55 dengan GGA dan 232 tanpa GGA, dilibatkan dalam penelitian ini. Dibandingkan dengan pasien tanpa GGA, pasien GGA lebih tua, terutama laki-laki, dan lebih mungkin untuk terjadi hipoksia dan memiliki penyakit hipertensi dan serebrovaskular yang sudah ada sebelumnya. Insiden GGA stadium 1 adalah $14,3 \%$, dan kejadian GGA stadium 2 dan 3 adalah 4,9\%. Pasien dengan GGA memiliki angka kematian yang jauh lebih tinggi.

116 pasien

Dari 116 pasien, GGA berkembang pada $21(18,1 \%)$ pasien. Diantaranya, GGA awal dan akhir ditemukan masing-masing pada $13(11,2 \%)$ dan $8(6,9 \%)$ pasien. Dibandingkan dengan pasien tanpa GGA, pasien dengan GGA memiliki disfungsi organ yang lebih parah, yang ditunjukkan dengan tingkat status keparahan penyakit yang lebih tinggi, sequential organ failure assessment (SOFA) yang lebih tinggi saat masuk, peningkatan prevalensi syok, dan tingkat pernapasan yang lebih tinggi. Pasien dengan GGA memiliki skor SOFA yang lebih tinggi saat masuk $(4,5 \pm 2,1$ vs $2,8 \pm 1,4$, OR 1,498 , 95\% CI $(1,047-2,143)$ dan kematian di rumah sakit yang lebih besar $(57,1 \%$ vs $12,6 \%$, ATAU $3,998,95 \%$ CI 1,088-14,613) dibandingkan pasien tanpa GGA pada analisis univariat dan multivariat. Pasien dengan GGA terlambat, tetapi tidak dengan GGA dini, memiliki lama tinggal yang secara signifikan lebih lama (19,6 vs 9,6 hari, $\mathrm{p}=0,015)$.

5449 pasien Dari 5.449 pasien yang dirawat dengan COVID-19, GGA terjadi pada $1.993(36,6 \%)$ pasien. Stadium puncak GGA adalah stadium 1 sebesar 46,5\%, stadium 2 sebesar $22,4 \%$ dan stadium 3 sebesar $31,1 \%$. Dari jumlah tersebut, $14,3 \%$ membutuhkan renal replacement therapy (RRT). Di antara pasien dengan GGA, 694 meninggal (35\%), $519(26 \%)$ sembuh dan $780(39 \%)$ masih dirawat di rumah sakit. GGA sering terjadi pada pasien dengan penyakit COVID-19. Ini terjadi secara dini dan berhubungan sementara dengan gagal napas dengan prognosis yang buruk.

73 pasien Usia rata-rata di 73 pasien yang dilibatkan adalah sekitar 54 tahun; sekitar $60 \%$ adalah laki-laki, dan hampir 58\% adalah warga negara Bahrain. Dari pasien, 39,7\% (29) mengalami GGA selama rawat inap, dimana $11,0 \%$ mencapai stadium $1,15,1 \%$ mencapai stadium 2 , dan $13,7 \%$ mencapai stadium 3 . Dari semua pasien, 7 pasien $(9,6 \%)$ membutuhkan hemodialisis. Angka kematian di rumah sakit jauh lebih tinggi pada pasien dengan GGA $(\mathrm{P}<0,001)$

22 pasien

22 kasus COVID-19 pada penerima transplantasi ginjal (usia rata-rata 52 tahun [kisaran interkuartil 40,75-62,75 tahun]) dan eGFR 60 awal (mL/ menit/ 1,73 m2) (44,75$86,75)$. Pasien mengeluh batuk $(72,7 \%)$, dispnea $(63,6 \%)$, demam $(68,2 \%)$, dan dingin $(72,7 \%)$ dengan prevalensi lebih tinggi. Hasil CT scan pada $90,9 \%$ pasien ditemukan lesi multifokal bilateral. GGA diamati pada
Cohort study

Retrospective cohort study

Retrospective cohort study

Cohort study

Retrospective cohort study

Descriptive observational study 
Hospital, Rasht, Iran

Yichun Cheng et al, 701 pasien
2020. ${ }^{14}$
Kidney disease is
associated with in hos-
pital death of patients
with COVID-19

Jia H. Ng et al, 2020. ${ }^{15}$ Outcomes among patients hospitalized with COVID-19 and acute kidney injury

9657 pasien
100 pasien

Adrien Joseph et al, $2020 .{ }^{16}$

Acute kidney injury in patients with SARS$\mathrm{CoV}-2$ infection
12 pasien selama rawat inap. Enam pasien meninggal setelah rata-rata 12 hari sejak masuk (IQR, 1-21).

Selama masa penelitian, GGA terjadi pada $5,1 \%$ pasien menunjukkan bahwa pasien dengan penyakit ginjal memiliki risiko kematian di rumah sakit yang secara signifikan lebih tinggi. Dan didapatkan prevalensi penyakit ginjal saat masuk dan perkembangan terjadi GGA selama rawat inap pada pasien dengan COVID-19 ialah tinggi dan dikaitkan dengan kematian di rumah sakit

tingkat kejadian GGA adalah 38,4/ 1.000 pasien-hari. Angka kejadian kematian di rumah sakit pada pasien tanpa GGA, dengan GGA tidak memerlukan dialisis (GGA stadium 1-3), dan dengan GGA yang menerima dialisis (GGA 3D) masing-masing adalah 10,8, 31,1, dan 37,5/ 1.000 pasien-hari. Di antara pasien dengan GGA 13 yang bertahan, $74,1 \%$ mencapai pemulihan ginjal pada saat keluar. Di antara mereka dengan GGA 3D yang selamat, 30,6\% tetap menjalani dialisis saat pulang, dan penyakit ginjal kronis pra-rawat inap adalah satu-satunya faktor risiko independen yang berhubungan dengan kebutuhan dialisis pasien saat pulang

Secara keseluruhan, 100 pasien COVID-19 dirawat. GGA terjadi pada 81 pasien $(81 \%)$, termasuk 44,10 , dan 27 pasien dengan GGA stadium 1, 2, dan 3 masingmasing. Derajat keparahan GGA dikaitkan dengan kematian pada hari ke-28
Cohort study

Retrospective cohort study

\section{Retrospective} cohort study

\section{BAHASAN}

Penelitian Yin et $\mathrm{al}^{7}$ menyatakan bahwa $46(13,4 \%)$ pasien mengalami GGA dan 35 pasien $(76,1 \%)$ di antaranya meninggal. Usia, jumlah leukosit, konsentrasi fibrinogen, kadar C-reaktif protein, dan keparahan pneumonia saat masuk rumah sakit merupakan faktor risiko independen yang terkait dengan kejadian GGA.

$\mathrm{Na}$ et $\mathrm{al}^{8}$ menyatakan bahwa pada pasien COVID-19, klasifikasi klinis sesuai pedoman National Health Commission of China (versi 7) dibagi menjadi kasus ringan, sedang, dan berat. Terdapat 21 kasus ringan, 37 kasus sedang, dan 8 kasus berat. Sebanyak 3 pasien dengan GGA termasuk dalam kasus yang parah $(\mathrm{p}=0,001)$. Untuk 3 pasien GGA, dipastikan bahwa agen nefrotoksik lebih mungkin menjadi penyebab dibandingkan penyebab GGA lainnya. Ketiga pasien menggunakan vankomisin, dan GGA berkembang setelah menggunakan vankomisin.

Penelitian dari Xiao et $\mathrm{al}^{9}$ melaporkan bahwa dibandingkan dengan pasien tanpa GGA, pasien GGA yang lebih tua, terutama laki-laki, dan lebih mungkin untuk yang datang dengan keluhan hipoksia dan memiliki penyakit hipertensi dan serebrovaskular yang sudah ada sebelumnya. Insiden GGA stadium 1 ialah 14,3\%, dan kejadian GGA stadium 2 dan 3 ialah 4,9\%. Pasien dengan GGA memiliki angka kematian yang jauh lebih tinggi (tanpa GGA: 7 pasien, GGA stadium 1: 3 pasien, dan GGA stadium 2-3: 9 pasien).

Searah dengan penelitian lainnya, Cui et al ${ }^{10}$ melaporkan bahwa GGA terjadi pada 21 pasien $(18,1 \%)$ dari 116 pasien dengan COVID-19. Pasien dengan GGA memiliki angka kematian di rumah sakit yang lebih tinggi daripada pasien tanpa GGA baik pada analisis univariat dan multivariat $(57,1$ vs $12,6 \%, \mathrm{p}=0,000$ ).

Penelitian Hirsch et al ${ }^{11}$ mendapatkan bahwa dari 5.449 pasien yang dirawat dengan Covid-19, GGA terjadi pada 1.993 pasien $(36,6 \%)$. Stadium puncak GGA ialah stadium 1 sebesar $46,5 \%$, stadium 2 sebesar $22,4 \%$, dan stadium 3 sebesar 31,1\%. Dari jumlah tersebut, $14,3 \%$ membutuhkan renal replacement theraphy (RRT). GGA terutama terlihat pada pasien COVID-19 dengan kegagalan pernapasan, dan $89,7 \%$ pasien 
yang menggunakan ventilasi mekanis juga lebih tinggi mengakibatkan GGA dibandingkan dengan pasien tanpa ventilasi $(21,7 \%)$. Dari pasien yang membutuhkan ventilasi dan berkembang menjadi GGA, 52,2\% memiliki onset GGA dalam 24 jam setelah intubasi. Faktor risiko GGA termasuk usia yang lebih tua, diabetes melitus, penyakit kardiovaskular, ras kulit hitam, hipertensi dan kebutuhan ventilasi dan obatobatan vasopresor. Di antara pasien dengan GGA, 694 meninggal (35\%), 519 (26\%) dipulangkan, dan $780(39 \%)$ masih dirawat di rumah sakit.

Taher et al $^{12}$ mendapatkan bahwa di antara 29 pasien $(39,7 \%)$ yang terkena GGA selama rawat inap, 7 pasien $(9,6 \%)$ membutuhkan hemodialisis. Penyakit ginjal kronis meningkatkan risiko GGA $(\mathrm{p}=0,003)$ seperti halnya status kritis COVID-19 $(p<0,001)$ dan kebutuhan ventilasi mekanis atau perawatan intensif $(\mathrm{p}<0,001$ untuk keduanya). Akhirnya, angka kematian di rumah sakit jauh lebih tinggi pada pasien dengan GGA $(\mathrm{P}<0,001) .{ }^{12}$

Hasil penelitian Monfared et a ${ }^{13}$ mendapatkan bahwa GGA saat masuk atau GGA yang berkembang selama rawat inap terjadi pada lebih dari setengah pasien transplantasi ginjal dengan COVID-19, dan 50\% di antaranya meninggal. Prevalensi penyakit ginjal saat masuk dan perkembangan GGA selama rawat inap pada pasien dengan COVID-19 tinggi dan berhubungan dengan kematian di rumah sakit.

Cheng et al ${ }^{14}$ melaporkan bahwa selama rawat inap, GGA terjadi pada 36 pasien $(5,1 \%)$. Insiden GGA secara bermakna lebih tinggi pada pasien dengan peningkatan serum kreatinin dasar $(11,9 \%)$ dibandingkan pada pasien dengan nilai dasar normal $(4,0 \%)$. Kematian di rumah sakit terjadi pada $16,1 \%$ pasien. Waktu rerata kematian ialah 6 hari (kisaran interkuartil: 3-12 hari). Insiden kematian di rumah sakit pada pasien dengan peningkatan serum kreatinin dasar ialah $33,7 \%$, yang secara bermakna lebih tinggi dibandingkan mereka dengan serum kreatinin dasar normal $(13,2 \%)$.

Hasil penelitian $\mathrm{Ng}$ et al ${ }^{15}$ menyatakan bahwa sebanyak 3.854/9.657 (39,9\%) pasien berkembang menjadi GGA, di antaranya 3.216/ 9.657 (33,3\%) memiliki GGA stadium 1-3 (1.644 dengan stadium 1 [17\%], 840 dengan stadium 2 [8,7\%], dan 732 dengan tahap 3 [7,6\%]) dan $638(6,6 \%)$ memiliki GGA stadium 3+dialisis. Setelah memperhitungkan waktu tindak lanjut, angka kejadian GGA ialah 38,3/1.000 pasien/hari, dengan angka kejadian GGA stadium 1-3 dan GGA stadium 3+dialisis masing-masing 32,0 dan 6,3/1.000 pasien tiap hari. Pasien dengan GGA yang memiliki proporsi lebih tinggi dengan kondisi komorbiditas termasuk diabetes melitus, penyakit arteri koroner, gagal jantung, dan penyakit ginjal kronis. Selain itu, kelompok GGA stadium 3+ dialisis memiliki tingkat penanda inflamasi tertinggi (D-dimer, Creaktif protein, dan serum feritin) diikuti oleh kelompok GGA stadium 1-3 dan kelompok non-GGA.

Penelitian Joseph et $\mathrm{al}^{16}$ melaporkan bahwa GGA terjadi pada 81 pasien $(81 \%)$ yang meliputi 44 pasien, 10 pasien, 27 pasien dengan GGA stadium 1, 2, dan 3 masing-masing. Di antara pasien dengan GGA, 33 (41\%) hanya memenuhi kriteria Kidney Disease: Improving Global Outcome (KDIGO) keluaran urin, 28 (35\%) hanya memenuhi kriteria kreatinin, dan 20 (25\%) memenuhi keduanya. Tiga belas (13\%) membutuhkan terapi penggantian ginjal selama 7 hari pertama di ICU. Pasien yang meninggal lebih tua (66 versus 57 tahun, $\mathrm{p}=0,001)$. Baik komorbiditas maupun IMT tidak dikaitkan dengan kematian pada hari ke 28. Pasien yang meninggal lebih sering memerlukan ventilasi mekanis (90 versus $41 \%, \mathrm{p}<0,001$ ), vasopresor (90 versus $36 \%, \mathrm{p}<0,001)$ dan terapi penggantian ginjal (31 versus $6 \%, p=0,002$ ).

Hasil penelitian ini memperlihatkan gambaran distribusi 10 artikel berdasarkan usia, jenis kelamin, riwayat penyakit, dan hasil laboratorium pasien yang berkaitan dengan penyakit gangguan ginjal akut dan pneumonia COVID-19. Berdasarkan kajian artikel tersebut, didapatkan distribusi mean (rerata) usia termuda pasien pneumonia COVID-19 yang mengalami gangguan ginjal akut dari penelitian $\mathrm{Na}$ et $\mathrm{al}^{8}$ yaitu 
45,6 tahun, sedangkan median (nilai tengah) usia tertua berasal dari penelitian $\mathrm{Ng}$ et al ${ }^{15}$ yaitu 71 tahun untuk pasien GGA stadium 13. Pada semua artikel didapatkan jenis kelamin laki-laki yang mendominasi sampel penelitian $(52,4-73 \%)$. Untuk riwayat penyakit pada sampel masing-masing penelitian sangat bervariasi, namun, didominasi oleh beberapa penyakit yaitu hipertensi, diabetes melitus, PPOK, penyakit kardiovaskuler, dan penyakit pernapasan. Demikian pula hasil laboratorium pasien yang diperiksa dan dicantumkan juga sangat bervariasi

\section{SIMPULAN}

Gangguan ginjal akut merupakan komplikasi pada pneumonia COVID-19. Pasien pneumonia COVID-19 dengan gangguan ginjal akut memiliki angka kematian yang lebih tinggi dibandingkan dengan pasien pneumonia COVID-19 tanpa gangguan ginjal akut di rumah sakit. Faktor risiko gangguan ginjal akut pada pneumonia COVID-19, antara lain: penggunaan obat yang bersifat nefrotoksik, memiliki komorbid (usia tua, diabetes melitus, penyakit kardiovaskular, penyakit ginjal kronis, dll)

\section{Konflik Kepentingan}

Penulis menyatakan tidak terdapat konflik kepentingan dalam studi ini.

\section{DAFTAR PUSTAKA}

1. Wiersinga WJ, Rhodes A, Cheng AC, Peacock SJ, Prescott HC. Pathophysiology, transmission, diagnosis, and treatment of coronavirus disease 2019 (COVID-19): a review. JAMA. 2020;324(8):782-93.

2. Aziza L, Aqmarina AMI, editors. Kementerian Kesehatan RI. Pedoman Pencegahan dan Pengendalian Coronavirus Disease (COVID-19). Jakarta: Kementerian Kesehatan RI, 2020.

3. World Health Organization. Total WHO coronavirus disease (COVID-19) Dashboard. 2020. Available from: https:// covid19. who.int/?gclid=Cj0KCQiA9P _BRC0ARIsAEZ6irh3eqMdk48sKejci nzl3C1fMkm0QXEnoNNw6NKCQS0 8uZ19qKkf168aAnvTEALw_wcB

4. Pei G, Zhang Z, Peng J, Liu L, Zhang C, Yu C, et al. Renal involvement and early prognosis in patients with COVID-19 pneumonia. J Am Soc Nephrol. 2020; 31(6):1157-65.

5. Judd E, Sanders PW, Agarwal A. Diagnosis and clinical evaluation of acute kidney injury. Comprehensive Clinical Nephrology Expert Consult (6th ed). Edinburgh: Elsevier Inc, 2016; p. 810-9.

6. Jiang F, Deng L, Zhang L, Cai Y, Cheung CW, Xia Z. Review of the clinical characteristics of coronavirus disease 2019 (COVID-19). J Gen Intern Med. 2020; 35(5):1545-9.

7. Jin K, Xie T, Seery S, Ye L, Jiang J, Yang W, et al. Acute kidney injury in COVID-19: clinical outcomes and risk factors. Res Sq. 2020. DOI: https://doi.org/10. 21203/rs.3.rs-37577/v1.

8. Na KR, Kim HR, Ham Y, Choi DE, Lee KW, Moon JY, et al. Acute kidney injury and kidney damage in COVID-19 patients. J Korean Med Sci. 2020;35(28):1-9.

9. Xiao G, Hu H, Wu F, Sha T, Huang Q, Li H, et al. Acute kidney injury in patients hospitalized with COVID-19 in Wuhan, China: A single-center retrospective observational study. medRxiv. 2020;128. Doi: https://doi.org/10.1101/2020. 04.06.20055194

10. Cui X, Yu X, Wu X, Huang L, Tian Y, Huang $\mathrm{X}$, et al. Acute kidney injury in patients with the coronavirus disease 2019: a multicenter study. Kidney Blood Press Res. 2020;45(4):612-22.

11. Hirsch JS, Ng JH, Ross DW, Sharma P, Shah $\mathrm{HH}$, Barnett RL, et al. Acute kidney injury in patients hospitalized with COVID-19. Kidney Int. 2020;98(1): 209-18.

12. Taher A, Alalwan AA, Naser N, Alsegai O, Alaradi A. Acute kidney injury in COVID-19 pneumonia: a single-center experience in Bahrain. Cureus. 2020; 12(February):1-14.

13. Monfared A, Dashti-Khavidaki S, Jafari R, Jafari A, Ramezanzade E, Lebadi MK, et al. Clinical characteristics and outcome of COVID-19 pneumonia in kidney transplant recipients in Razi hospital, Rasht, Iran. Transpl Infect Dis. 2020;(May):1-8.

14. Cheng Y, Luo R, Wang K, Zhang M, Wang Z, Dong $\mathrm{L}$, et al. Kidney disease is associated with in-hospital death of patients 
with COVID-19. Kidney Int. 2020; 97(5):829-38.

15. Ng JH, Hirsch JS, Hazzan A, Wanchoo R, Shah HH, Malieckal DA, et al. Outcomes among patients hospitalized with COVID-19 and acute kidney injury. Am J Kidney Dis. 2020;2. Available from: https://www.ajkd.org/
article/S0272- 6386(20)30998-7/fulltext 16. Joseph A, Zafrani L, Mabrouki A, Azoulay E, Darmon M. Acute kidney injury in patients with SARS-CoV-2 infection. Ann Intensive Care. 2020;10(1). Available from: https://annalsof intensive care.springeropen.com/articles/ 10.1186/s13613-020-00734-Z 